\title{
Kesulitan siswa SMA dalam menyelesaikan soal matematika pada materi peluang
}

\author{
Annisa Fitri 1, a, *, Agus Maman Abadi ${ }^{2, b}$ \\ ${ }^{1}$ Program Studi Magister Pendidikan Matematika, Universitas Negeri Yogyakarta \\ Jl. Colombo No. 1, Karangmalang, Yogyakarta 55821, Indonesia \\ ${ }^{2}$ Jurusan Pendidikan Matematika, Universitas Negeri Yogyakarta \\ Jl. Colombo No. 1, Karangmalang, Yogyakarta 55821, Indonesia \\ E-mail: ${ }^{a}$ aan.af.92@gmail.com, ${ }^{\mathrm{b}}$ agusmaman@uny.ac.id \\ * Corresponding Author
}

\section{ARTICLE INFO}

\section{Article history}

Received: 23 Nov. 2017

Revised: 10 Sept. 2021

Accepted: 11 Sept. 2021

\section{Keywords}

Kesulitan siswa, Newman's errors procedure, peluang, pembelajaran matematika, student's difficulties, probability

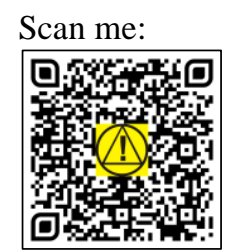

\section{ABSTRACT}

Penelitian ini bertujuan untuk mendeskripsikan jenis kesulitan siswa SMA dalam menyelesaikan soal matematika pada materi peluang di Kabupaten Indragiri Hilir. Penelitian ini termasuk penelitian survei dengan pendekatan kuantitatif dan kualitatif. Sampel penelitian sebanyak 284 siswa SMA kelas XI Program IPA di Kabupaten Indragiri Hilir, Indonesia, yang berasal dari sepuluh sekolah dengan kategori tinggi, sedang, dan rendah. Sampel penelitian ditentukan menggunakan teknik stratified propotional random sampling. Instrumen yang digunakan berupa tes yang telah divalidasi oleh ahli (expert judgement). Kesalahan siswa dijustifikasi berdasarkan Newman's errors categories. Hasil penelitian menunjukkan bahwa jenis kesulitan siswa dalam menyelesaikan soal matematika pada materi peluang yaitu kesulitan memahami masalah (comprehension errors) sebanyak 64,1\%; kesulitan melakukan transformasi (transformations errors) sebanyak 71,1\%; kesulitan keterampilan proses (processing skill errors) sebanyak 89,4\%; dan kesulitan menarik kesimpulan (encoding errors) sebanyak $94 \%$.

This study aimed to describe the types of difficulties high school students in solving mathematics problems on probability material in Indragiri Hilir Regency. This study includes a survey with quantitative and qualitative approaches. The research sample was 284 eleventh-grade high school students in the science program on Indragiri Hilir Regency, Indonesia, from ten schools with high, medium, and low categories. The research sample was determined using a stratified proportional random sampling technique. The instrument used was a test that has been validated by an expert. Students' errors were justified based on Newman's errors categories. The results showed that the types of students' difficulties in solving mathematics problems on the probability material, namely: difficulty in understanding the problem (comprehension errors) as many as $64.1 \%$; difficulty in making transformations (transformation errors) as many as $71.1 \%$; difficulty in process skill (processing skill errors) as many as $89.4 \%$; and difficulty in concluding (encoding errors) as many as $94 \%$.

How to Cite: Fitri, A., \& Abadi, A. M. (2021). Kesulitan siswa SMA dalam menyelesaikan soal matematika pada materi peluang. Jurnal Riset Pendidikan Matematika, 8(1), 96-105. https://doi.org/10.21831/jrpm.v8i1.17004

\section{PENDAHULUAN}

Matematika merupakan ilmu yang harus dikuasai dalam rangka mempersiapkan diri menghadapi masalah sehari-hari maupun sebagai tuntutan dunia kerja (Reys et al., 2012). NCTM (2000) menyatakan bahwa tuntutan pemahaman matematika akan terus meningkat dari waktu ke waktu. Hal ini dikarenakan kekuatan matematika yang mampu mengubah dunia. Kekuatan peran matematika terlihat dari aplikasi 
masalah matematika dalam kehidupan sehari-hari. Masalah aplikasi matematika berkaitan dengan pemecahan masalah matematika

Pemecahan masalah merupakan esensi penting dalam pembelajaran matematika banyak diungkapkan oleh para ahli dan dokumen kurikulum di dunia. Sebagaimana diungkapkan NCTM (2000) bahwa pemecahan masalah matematika merupakan tujuan dari pembelajaran matematika. Selain menjadi esensi penting dalam pembelajaran matematika, pemecahan masalah juga menjadi fokus yang menarik dalam pendidikan matematika.

Kemampuan pemecahan masalah dapat dilihat dari proses siswa dalam menyelesaikan masalah. Salah satu standar penilaian kemampuan pemecahan masalah matematika siswa yang berlaku secara nasional adalah Ujian Nasional. Ujian Nasional berperan sebagai penentu kelulusan siswa. Siswa dinyatakan lulus dalam menyelesaikan suatu jenjang pendidikan apabila siswa tersebut mampu mendapatkan nilai matematika yang sesuai dengan standar yang ditentukan. Hal ini menuntut siswa untuk lebih menguasai materi pelajaran dan meningkatkan kualitas pemahaman siswa agar mampu menyelesaikan masalah.

Potret pemahaman matematika siswa dalam menyelesaikan masalah dapat dilihat dari Ujian Nasional (UN). UN merupakan standar penilaian kemampuan matematika yang berstandar nasional. Sebagaimana diatur pada Peraturan Menteri Pendidikan dan Kebudayaan nomor 23 tahun 2016 Pasal 11, yaitu: (a) penilaian hasil belajar oleh Pemerintah dilakukan dalam bentuk Ujian Nasional (UN) dan/atau bentuk lain dalam rangka pengendalian mutu pendidikan, (b) penyelenggaraan UN oleh Badan Standar Nasional Pendidikan (BSNP) bekerja sama dengan instansi terkait untuk mengukur pencapaian kompetensi lulusan (Kemendikbud, 2016).

Pencapaian hasil nilai UN dapat dilihat berdasarkan provinsi, kabupaten ataupun sekolah oleh pihak BSNP. Kabupaten Indragiri Hilir sebagai salah satu kabupaten tertinggal yang ada di Provinsi Riau. Pencapaian rata-rata nilai UN matematika di Kabupaten Indragiri Hilir yang mengalami penurunan sebesar 10,23 pada tahun 2016. Berdasarkan daya serap materi, secara umum persentase daya serap setiap materi UN SMA/MA Program IPA pada Tahun Pelajaran 2014/2015 mengalami penurunan pada tahun 2015/2016.

Peluang merupakan salah satu materi yang disajikan dalam matematika sekolah. Akibatnya, materi ini diujikan pada Ujian Nasional. Materi statistika dan peluang merupakan materi dengan daya serap terendah pada UN SMA/MA Program IPA tahun 2015/2015. Standar kelulusan siswa setiap tahunnya juga semakin tinggi. Hal ini menuntut siswa untuk mampu menguasai mata pelajaran matematika dengan baik dan benar demi tercapainya hasil belajar yang maksimal termasuk pada materi peluang.

Rendahnya persentase daya serap siswa dalam penguasaan materi dapat disebabkan karena siswa banyak melakukan kesalahan dalam menyelesaikan soal (Rumasoreng \& Sugiman, 2014). Kenyataan di lapangan, berdasarkan hasil wawancara dengan guru matematika di Kabupaten Indragiri Hilir, pada saat siswa diberikan suatu permasalahan matematika yang sedikit berbeda dengan contoh yang telah diberikan guru maka banyak siswa menyelesaikannya dengan menggunakan pengetahuannya sendiri yang terkadang kurang sesuai dengan prosedur sebenarnya. Hal ini mengakibatkan siswa melakukan kesalahan dalam menyelesaikan masalah matematika. Kesalahan ini terjadi karena siswa mengalami kesulitan dalam proses pemecahan masalah. Dengan kata lain, tidak semua siswa mampu melewati semua proses pemecahan masalah. Artinya, ada siswa yang mengalami kesulitan pada fase tertentu dalam memecahkan masalah (Abdullah et al., 2015).

Cooney et al. (1975, pp. 216-231) juga mengkaji kategori kesulitan yang meliputi kesulitan dalam menggunakan konsep, kesulitan dalam menggunakan prinsip dan kesulitan dalam memecahkan masalah verbal. Wijaya et al. (2014) dalam penelitiannya menemukan kesulitan pemahaman dan transformasi paling dominan dilakukan siswa. Hasil penelitian Phonapichat et al. (2014) tentang kesulitan dalam pemecahan masalah diperoleh informasi bahwa siswa mengalami kesulitan dalam: (a) memahami kata kunci yang muncul dalam masalah, sehingga tidak bisa menafsirkannya ke kalimat matematis; (b) siswa tidak dapat mengetahui apa yang harus diasumsikan dan informasi apa yang diperlukan untuk memecahkannya; (c) kapan pun siswa tidak mengerti masalahnya, mereka cenderung menebak jawabannya tanpa memikirkan proses apa pun; (d) siswa tidak sabar dan tidak suka membaca masalah matematika; (e) siswa tidak suka membaca masalah panjang.

Penelitian Dundar dan Yaman (2015) dalam mengerjakan soal non rutin sebagian besar kesulitan yang dilakukan guru dalam mengerjakan soal non rutin adalah sulit dalam membuat model matematika dari masalah yang diberikan. Kemudian, Abdullah et al. (2015) dalam penelitiannya yang menganalisis 
kesulitan siswa dalam menyelesaikan soal HOTS siswa persentase kesulitan yang paling dominan adalah pengkodean $(27,58 \%)$, diikuti dalam keterampilan proses $(27,33 \%)$, transformasi $(24,17 \%)$, dan pemahaman (20,92\%). Novferma (2016) dalam penelitiannya menemukan berbagai jenis kesulitan yaitu pada mengingat fakta, mengingat konsep, memahami fakta, memahami konsep, menerapkan konsep, menerapkan prosedur, menganalisis prosedur, mengevaluasi faktual, mengevaluasi konsep, mengevaluasi prosedur, dan mengomunikasikan metakognitif.

Kesulitan siswa dalam pemecahan masalah ini perlu dianalisis untuk meningkatkan kualitas penguasaan matematika siswa. Guru perlu menyadari dan mengetahui kesulitan apa yang dialami siswa dalam menyelesaikan masalah. Sehingga, sebagai evaluasi yang tepat dalam memperbaiki praktik pembelajaran ke depan. Akibatnya, kesulitan siswa dapat dikurangi dan kemampuan siswa dalam pemecahan masalah dapat ditingkatkan. Kesulitan siswa dapat dianalisis dari jawaban siswa dalam mengerjakan soal (Wijaya et al., 2014). Lembar jawaban siswa akan dianalisis untuk menentukan jenis kesulitan yang dialami siswa dalam proses pemecahan masalah. Untuk lebih memperdalam analisis jawaban siswa maka akan dikaji letak kesulitan siswa.

Pada penelitian ini soal yang diberikan siswa berupa tes berbentuk soal uraian. Soal dibuat mengacu pada indikator materi UN pada jenjang SMA/MA dari tahun pelajaran 2014/2015 sampai tahun 2015/2016. Soal dibuat merupakan soal dalam bentuk masalah non rutin. Masalah non rutin membutuhkan kemampuan berpikir dan penalaran yang lebih tinggi karena tidak diketahui langsung prosedur penyelesaiannya. Sebagaimana dijelaskan oleh Reys et al. (2012, p. 107) "by contrast, non routine problems that is true problems, generally require thinking because the mathematical procedures that children must use to solve them are not obvious". Kemampuan siswa dalam pemecahan masalah non rutin diperlukan untuk mengasah kemampuan berpikir dan bernalar siswa. Hal ini disampaikan Yazgan (2015, p. 1808) yang menyebutkan bahwa mempelajari bagaimana pemecahan masalah non rutin menjadi hal yang urgen karena membantu siswa menyelesaikan masalah yang asing dan lebih berkonteks. Siswa cenderung menggunakan penalaran dalam menyelesaikan masalah non rutin.

Analisis jenis dan letak kesulitan siswa dalam pemecahan masalah matematika non rutin tentang peluang pada penelitian ini digunakan Newman Error Categories (NEC) sebagaimana telah dilakukan oleh Wijaya et al. (2014) dalam menganalisis kesalahan siswa dalam pemecahan masalah context-based tasks. Artinya, peneliti melihat kesulitan dari kesalahan siswa dalam mengerjakan masalah matematika non rutin. Kemudian penelitian yang dilakukan Wasda (2015) jenis kesulitan yang dialami oleh siswa SMA di Kabupaten Ngada dalam menyelesaikan soal model Ujian Nasional matematika yaitu kesulitan dalam menyatakan fakta, kesulitan dalam memahami konsep, kesulitan dalam menerapkan prinsip dan kesulitan dalam menerapkan keterampilan. Selanjutnya, Abdullah et al. (2015) menganalisis jenis kesulitan yang dialami siswa dalam menyelesaikan soal HOTS menggunakan NEC.

Untuk mengetahui apakah kategori NEC cocok untuk menganalisis kesalahan siswa dalam pemecahan masalah matematika non rutin dari informasi yang diperoleh dari hasil tes diperlukan struktur yang jelas. Dalam hal ini peneliti membandingkan NEC dengan tahapan atau proses pemecahan masalah yang dijelaskan Polya yang disajikan pada Tabel 1. Berdasarkan Tabel 1 dapat disimpulkan bahwa pada kategori pertama yakni membaca tidak terdapat pada Polya namun sesuai dengan tahapan yang dikemukakan Krulik dan Rudnick jika dibandingkan dengan NEC. Untuk comprehension pada NEC sesuai dengan dua jenis tahapan yang dijelaskan pada tabel di atas yakni understanding the problem dan explore. Kategori ketiga adalah (transformation) sesuai dengan menyusun perencanaan dan memilih strategi serta menyederhanakan masalah yang berhubungan dengan transformasi. Kategori keempat yakni keterampilan proses berhubungan prosedur matematika dalam melaksanakan perencanaan dan proses pemecahan masalah. Selanjutnya kategori terakhir adalah representasi matematika juga berhubungan dengan meninjau, menafsirkan kembali solusi, dan memeriksa jawaban.

Berdasarkan alasan ini penulis menggunakan Newman's Error Categories karena memiliki kesamaan dengan tahapan dalam pemecahan masalah sehingga dapat digunakan untuk menganalisis kesulitan siswa dalam pemecahan masalah. Dengan kata lain, maka jenis kesulitan siswa dalam pemecahan masalah matematika non rutin yang digunakan pada penelitian ini meliputi: (1) kesulitan dalam memahami masalah; (2) kesulitan dalam mentransformasikan masalah; (3) kesulitan dalam keterampilan proses matematika; dan (3) kesulitan dalam encoding.

Penelitian ini bertujuan untuk mendeskripsikan jenis kesulitan yang dialami siswa SMA/MA dalam pemecahan masalah matematika non rutin di Kabupaten Indragiri Hilir. Analisis kesulitan juga 
Tabel 1. NEC dan tahapan pemecahan masalah

\begin{tabular}{|c|c|c|}
\hline \multirow{2}{*}{ Newman's error categories a } & \multicolumn{2}{|c|}{ Tahapan dalam pemecahan masalah } \\
\hline & Polya (1973) & Krulik \& Rudnick (1995) \\
\hline $\begin{array}{l}\text { Reading: Error in simple } \\
\text { recognition of words and } \\
\text { symbols }\end{array}$ & - & Read: idendtifies the problem \\
\hline $\begin{array}{l}\text { Comprehension: Error ini } \\
\text { understanding the meaning of a } \\
\text { problem }\end{array}$ & $\begin{array}{l}\text { Understanding the problem: } \\
\text { what is the unknown? What } \\
\text { are data? }\end{array}$ & Explore: identify the problem \\
\hline $\begin{array}{l}\text { Transformation: Error in } \\
\text { transforming a word problem } \\
\text { into an appropriate } \\
\text { mathematical problema }\end{array}$ & $\begin{array}{l}\text { Devising a plan: Find the } \\
\text { connection between the data } \\
\text { and unknown, make } \\
\text { mathematical model }\end{array}$ & $\begin{array}{l}\text { Select a strategy:makes } \\
\text { hypothesis about how to } \\
\text { solve the problem, looks for } \\
\text { simple problem }\end{array}$ \\
\hline $\begin{array}{l}\text { Process skills: Error in } \\
\text { performing mathematical } \\
\text { procedures }\end{array}$ & Carrying out the plan & $\begin{array}{l}\text { Solve: once the method has } \\
\text { been selected and applies it } \\
\text { to the problem }\end{array}$ \\
\hline $\begin{array}{l}\text { Encoding: Error in representing } \\
\text { the mathematical solution into } \\
\text { acceptable written form }\end{array}$ & $\begin{array}{l}\text { Looking back: check the } \\
\text { result }\end{array}$ & $\begin{array}{l}\text { Review and Extend: } \\
\text { Verifies the answers and looks } \\
\text { for variations in the method } \\
\text { of solving the problem }\end{array}$ \\
\hline
\end{tabular}

Sumber: ${ }^{a}$ Wijaya et al. (2014)

bertujuan memberikan kontribusi untuk meningkatkan kualitas pembelajaran matematika. Hal ini karena dengan mengetahui kesulitan akan memberikan bantuan pada guru terkait pengambilan sikap bahkan kebijakan untuk mengatasi kesulitan siswa. Akibatnya, kemampuan pemecahan masalah matematika siswa dapat ditingkatkan. Dengan kata lain, implikasi penelitian ini adalah dapat menjadi rujukan dalam upaya meningkatkan mutu pendidikan saat ini khususnya pemecahan masalah matematika siswa sekaligus sebagai upaya meningkatkan UN matematika di Kabupaten Indragiri Hilir.

\section{METODE}

Penelitian survei ini bertujuan untuk mendeskripsikan kesulitan yang dialami siswa dalam menyelesaikan masalah non rutin. Jenis penelitian survei dipilih dengan pertimbangan bahwa penelitian bertujuan untuk memperoleh gambaran tentang keadaan populasi secara alami. Deskripsi yang dimaksud adalah deskripsi tentang kesulitan dalam pemecahan masalah matematika non rutin di kelas XI IPA SMA/MA Kabupaten Indragiri Hilir.

Populasi pada penelitian ini adalah seluruh siswa SMA/MA kelas XI yang berjumlah 31 sekolah. Teknik pengambilan sampel yang digunakan adalah stratified proportional random sampling yakni penentuan sampel dengan memperhatikan strata-strata tertentu dalam populasi. Teknik ini merupakan penggalan dari stratified sampling (sampling bertingkat) dan proportional sampling (sampling proporsional) dilanjutkan dengan random sampling (sampling acak). Teknik sampling proporsional digunakan untuk menentukan sampel secara proporsional untuk setiap strata. Sehingga pada penelitian ini terpilih

Tabel 2. Daftar sekolah sampel penelitian

\begin{tabular}{ll}
\hline \multicolumn{1}{c}{ Strata } & Nama sekolah \\
\hline Tinggi & MA Nurul Hidayah \\
& SMA Negeri Gaung Anak Serka \\
& SMA PGRI Tembilahan \\
\multirow{3}{*}{ Sedang } & MA Negeri Tembilahan \\
& MA Negeri Kuala Enok \\
& SMA Negeri 2 Tembilahan \\
\multirow{3}{*}{ Rendah } & SMA Negeri 1 Gaung \\
& SMA Negeri 1 Tanah Merah \\
& SMA Negeri 1 Enok \\
& MA Al-Ikhlas Sungai Guntung \\
\hline
\end{tabular}


4 sekolah strata tinggi, 3 sekolah strata sedang, dan 3 sekolah strata tinggi. Jumlah populasi sebanyak 1350 siswa. Untuk menentukan sampel minimal $(n)$ digunakan tabel penentuan jumlah sampel Krejcie dan Morgan (Wagiran, 2015, p. 172) diperoleh sampel minimum 279 siswa. Adapun sekolah yang terpilih untuk menjadi sampel penelitian disajikan pada Tabel 2.

Teknik pengumpulan data yang digunakan dalam penelitian berupa tes (masalah non rutin). Tes digunakan untuk mengumpulkan data jawaban dan langkah pengerjaan siswa dalam menyelesaikan masalah. Instrumen tes berupa masalah non rutin yang berbentuk uraian agar mudah menganalisis kesulitan siswa dalam mengerjakan masalah non rutin dari hasil pekerjaan siswa. Kisi-kisi soal disusun berdasarkan indikator UN pada materi peluang. Soal yang dibuat peneliti untuk materi peluang adalah sebagai berikut:

\section{Soal.}

Mahasiswa relawan dari beberapa fakultas di Universitas Islam Indragiri akan memberikan bantuannya terhadap korban longsor di Kecamatan Tanah Merah. Satu dari relawan tersebut akan dipilih untuk diwawancarai tentang keadaan warga Kecamatan Tanah Merah untuk memberikan informasi tentang keadaan pasca longsor di stasiun TV daerah. Tentukan peluang orang yang terpilih tersebut adalah wanita atau berasal dari fakultas keguruan jika data mahasiswa relawan adalah sebagai berikut.

\begin{tabular}{|l|l|l|l|}
\hline Fakultas & Wanita & Laki-laki & Total \\
\hline Keguruan & 17 & 20 & 37 \\
\hline Ekonomi & 22 & 17 & 39 \\
\hline Teknik & 8 & 7 & 15 \\
\hline Perikanan & 4 & 1 & 5 \\
\hline Hukum & 2 & 2 & 4 \\
\hline Jumlah & 53 & 47 & 100 \\
\hline
\end{tabular}

Pada penelitian ini validasi instrumen menggunakan validitas isi. Pembuktian validitas isi dilakukan dengan meminta penilaian dari dua dosen ahli dalam matematika. Hasil validasi terhadap instrumen tes menunjukkan bahwa seluruh item valid. Hasil estimasi reliabilitas menunjukkan bahwa instrumen tes memiliki koefisien reliabilitas sebesar 0,765 berada pada kategori sangat tinggi.

Analisis data dilakukan secara secara deskriptif. Analisis berupa deskripsi hasil tes diagnostik yang diperiksa dengan melihat penyelesaian soal oleh siswa (menjawab benar, benar tetapi kurang lengkap, salah menyelesaikan, tidak selesai, atau tidak mengerjakan). Jawaban siswa dalam mengerjakan tes diagnostik yang berbentuk uraian, diperiksa berdasarkan skor kesulitan siswa yang ditentukan dengan menggunakan pedoman penskoran tes. Selanjutnya jawaban siswa yang salah dianalisis dengan meng-

Tabel 3. Skema pengkodean kesulitan siswa dalam pemecahan masalah

\begin{tabular}{lc}
\hline Jenis kesalahan & Penjelasan \\
\hline Pemahaman & Siswa tidak dapat memahami apa saja yang diketahui dan \\
& ditanyakan pada soal dengan lengkap. \\
& Siswa tidak dapat membedakan informasi yang relevan dan \\
tidak relevan. & \\
Transformasi & Siswa tidak dapat membuat model/rumus matematis. Siswa \\
& cenderung menggunakan secara langsung prosedur \\
& matematis (seperti rumus, algoritma) tanpa menganalisis \\
& apakah diperlukan atau tidak. \\
& Siswa tidak mengetahui prosedur/langkah yang akan diguna- \\
& kan untuk menyelesaikan soal dengan tepat. \\
& Siswa tidak dapat melanjutkan prosedur/langkah penyele- \\
& saian. Siswa melakukan kesalahan dalam melakukan kom- \\
& putasi. Siswa menggunakan formula atau prosedur yang \\
Keterampilan proses & benar, namun tidak menyelesaikannya. \\
& Siswa tidak dapat menemukan hasil akhir sesuai prosedur/ \\
& langkah yang digunakan atau tidak dapat menuliskan \\
jawaban akhir sesuai yang dimaksud soal.
\end{tabular}


gunakan coding scheme (skema pengkodean) yang dikembangkan dari jenis kesalahan Newman menurut Wijaya et al. (2014). Skema pengkodean yang dimaksud disajikan pada Tabel 3. Setelah dilakukan pemeriksaan dan analisis yang mendalam, tahap terakhir yaitu membuat kesimpulan. Berdasarkan analisis terhadap data hasil tes masalah non rutin dilakukan penarikan kesimpulan berupa analisis jenis kesulitan yang dialami subyek penelitian dalam menyelesaikan masalah.

\section{HASIL DAN PEMBAHASAN}

Dalam penelitian ini peneliti mengumpulkan informasi dari hasil jawaban tes diagnostik siswa yang selanjutnya dideskripsikan dan dianalisis jenis kesalahannya berdasarkan kesalahan Newman. Jawaban penyelesaian siswa dikoreksi dengan melihat banyaknya siswa menjawab benar, benar tetapi kurang lengkap, salah menyelesaikan, tidak mengerjakan, dan tidak selesai pada Tabel 4.

Tabel 4. Hasil jawaban tes diagnostik $(n=284)$ dalam menyelesaikan soal materi peluang

\begin{tabular}{lcc}
\hline Penyelesaian siswa & Jumlah jawaban & Persentase (\%) \\
\hline Benar Kurang Lengkap (BKL) & 13 & 4,6 \\
Menjawab Benar (MB) & 18 & 6,3 \\
Salah Mengerjakan (SM) & 144 & 50,7 \\
Tidak Mengerjakan (TM) & 55 & 19,3 \\
Tidak Selesai Mengerjakan (TSM) & 54 & 19 \\
Total & 284 & 100 \\
\hline
\end{tabular}

Berdasarkan Tabel 4 diperoleh informasi bahwa sebagian besar siswa masih salah dalam menyelesaikan masalah non rutin. Salah dalam menyelesaikan soal menjadi indikasi bahwa banyak siswa yang mengalami kesulitan dalam pemecahan masalah matematika non rutin pada materi peluang. Masing-masing siswa diberikan tes yang terdiri dari 1 butir soal tentang materi peluang. Dari seluruh hasil pekerjaan tersebut didapatkan bahwa siswa yang benar menyelesaikan namun kurang lengkap ada 13 jawaban (4,6\%), menjawab benar ada 18 jawaban (6,3\%), salah mengerjakan ada 144 jawaban (50,7\%), tidak mengerjakan ada 55 jawaban $(19,3)$, dan tidak selesai mengerjakan ada 54 jawaban (19\%).

Pada penelitian ini, selain mendeskripsikan hasil jawaban dari tes, peneliti juga mendeskripsikan skor kesulitan siswa berdasarkan pedoman skor kesulitan yang telah dibuat. Hasil penelitian diperoleh bahwa rata-rata skor kesulitan yang paling tinggi yaitu pada kesulitan keterampilan proses sebesar 1,9 diikuti rata-rata kesulitan encoding sebesar 1,7 dan kesalahan transformasi sebesar 0,9 . Selanjutnya ratarata kesulitan pemahaman sebesar 0,8 .

Jenis kesalahan siswa pada penelitian ini berdasarkan tes diagnostik secara keseluruhan terlihat pada Tabel 5.

Tabel 5. Persentase jenis kesulitan siswa berdasarkan tes masalah non rutin $(n=284)$ pada materi peluang

\begin{tabular}{lcc}
\hline Jenis kesalahan & Jumlah & Persentase (\%) \\
\hline Kesulitan Pemahaman (KC) & 182 & 64,1 \\
Kesulitan Transformasi (KT) & 202 & 71,1 \\
Kesalahan Keterampilan Proses (KTP) & 254 & 89,4 \\
Kesulitan Encoding (KE) & 268 & 94 \\
\hline
\end{tabular}

Berdasarkan Tabel 5 diperoleh informasi bahwa persentase jenis kesulitan yang paling dominan dialami siswa dalam pemecahan masalah non rutin adalah kesulitan dalam menyimpulkan jawaban akhir (encoding) sebesar 94\%. Kemudian, kesulitan keterampilan proses sebesar 89,4\%, kesulitan transformasi se-

Tabel 6. Persentase jenis kesulitan siswa pada materi peluang berdasarkan kategori sekolah

\begin{tabular}{lccc}
\hline \multirow{2}{*}{ Jenis kesalahan } & \multicolumn{3}{c}{ Kategori sekolah } \\
\cline { 2 - 4 } & Tinggi & Sedang & Rendah \\
\hline KC & 27,6 & 23,3 & 29,8 \\
KT & 57,9 & 46 & 55,6 \\
KTP & 79,3 & 90,5 & 90,2 \\
KE & 84,1 & 92,3 & 92,9 \\
\hline
\end{tabular}


besar $71,1 \%$ dan kesulitan pemahaman sebagai persentase kesulitan yang paling kecil dialami yakni sebesar $64,1 \%$.

Dari 10 sekolah yang dipilih berdasarkan kategori sekolah berstrata tinggi (116 siswa), sedang (86 siswa), dan rendah (82 siswa) diperoleh persentase jenis kesalahan siswa pada Tabel 6. Berdasarkan Tabel 6, kategori sekolah berstrata tinggi, sedang dan rendah yang paling dominan berada pada jenis kesulitan menyampaikan jawaban akhir pada materi peluang.

\section{Pembahasan}

Pada penelitian ini, jenis kesulitan yang dialami siswa dalam memahami masalah adalah kesulitan yang paling sedikit terjadi dibandingkan jenis kesulitan lainnya. Contoh kesulitan dalam pemahaman terkait soal pada materi peluang ini disajikan pada Gambar 1.

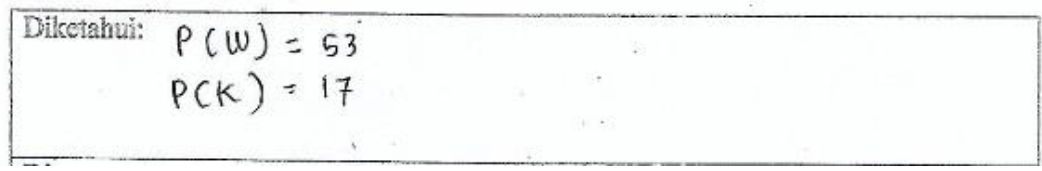

Gambar 1. Kesulitan siswa dalam menentukan apa yang diketahui

Pada Gambar 1 kesulitan yang dialami siswa dalam menentukan apa yang diketahui. Siswa menuliskan banyak jumlah wanita bukan peluang wanita. Kesalahan seperti ini banyak dialami siswa, hal ini dikarenakan siswa kurang memahami konsep peluang dengan benar dan salah menerima informasi yang diberikan soal. Kemudian, akan disajikan contoh kesulitan siswa dalam memahami apa yang ditanyakan pada soal, seperti disajikan pada Gambar 2.

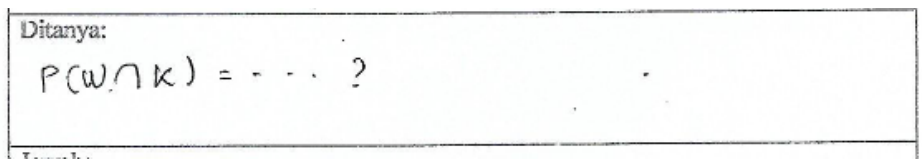

Gambar 2. Kesulitan siswa dalam menentukan apa yang ditanya

Pada Gambar 2 siswa menulis kesulitan terlihat bahwa siswa tidak mampu menuliskan apa yang ditanya soal dengan benar. Butir soal 2 menanyakan peluang terpilihnya wanita atau keguruan. Pada gambar terlihat bahwa siswa menuliskan peluang terpilihnya wanita dan keguruan. Hal ini dapat dikarenakan siswa keliru antara gabungan dengan irisan dari suatu kejadian.

Kenyataan yang ditemukan mengenai kesulitan siswa dalam menentukan apa yang diketahui dan ditanya diungkap oleh Cooney et al. (1975, p. 222) bahwa beberapa siswa cenderung untuk menghafal prinsip sebagai fakta. Artinya, siswa membaca soal namun belum mampu memahami informasi yang diberikan soal. Kesulitan pada aspek ini dipengaruhi kemampuan membaca siswa sebagaimana dikemukakan oleh Phonapichat et al. (2014, p. 3171) "the importance of reading skills to mathematics has been studied in several aspects, like the interrelation between reading and mathematics achievement".

Kesulitan selanjutnya yaitu jenis kesulitan transformasi yaitu siswa salah atau bahkan tidak bisa menentukan langkah-langkah yang digunakan untuk menyelesaikan soal (lihat Gambar 3). Selain itu ada juga siswa yang hanya menuliskan rumusnya saja tanpa menentukan sistem penyelesaian selanjutnya seperti apa. Zakaria (2010, p. 105) dalam penelitiannya menemukan bahwa banyak siswa mengalami kesulitan dalam transformasi dan keterampilan proses menyelesaikan masalah.

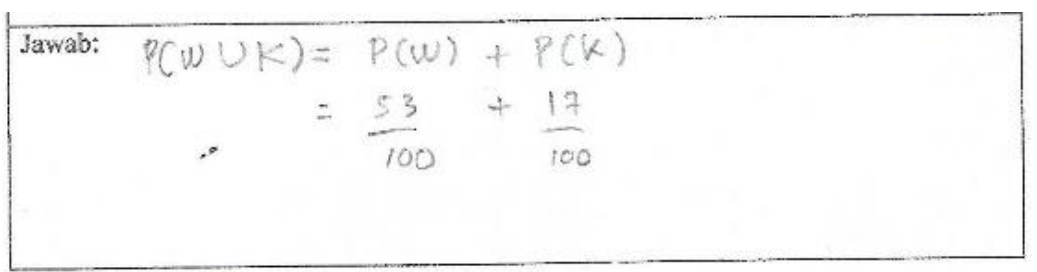

Gambar 3. Kesulitan siswa dalam transformasi pada materi peluang

Gambar 3 menunjukkan kesulitan dalam menentukan rumus yang tepat juga dialami oleh siswa dalam menyelesaikan masalah non rutin. Siswa menuliskan rumus peluang dua kejadian saling lepas, 
namun pada butir soal 2 berkaitan dengan peluang dua kejadian yang tidak saling lepas. Hal ini dikarenakan siswa kurang memahami informasi yang disajikan pada tabel dengan benar. Hal ini terlihat juga dari kekeliruan siswa menuliskan jumlah keguruan sebanyak 17 orang karena seharusnya ada 37 orang.

Jenis kesulitan pada tahap keterampilan proses matematika merupakan kesulitan yang termasuk banyak dialami siswa. Kesulitan ini mengakibatkan siswa tidak mampu melakukan tahapan dengan lengkap, kesalahan dalam operasi dasar matematika dan memproses variabel. Hal ini sesuai dengan pendapat Singh (2010, p. 266) bahwa kesulitan keterampilan proses terjadi apabila siswa mampu memilih operasi yang diperlukan untuk menyelesaikan persoalan namun ia tak dapat menjalankan prosedur dengan benar, seperti halnya menggunakan informasi yang ada pada soal. Contoh kesulitan keterampilan proses matematika pada materi peluang yang dialami siswa disajikan pada Gambar 4.

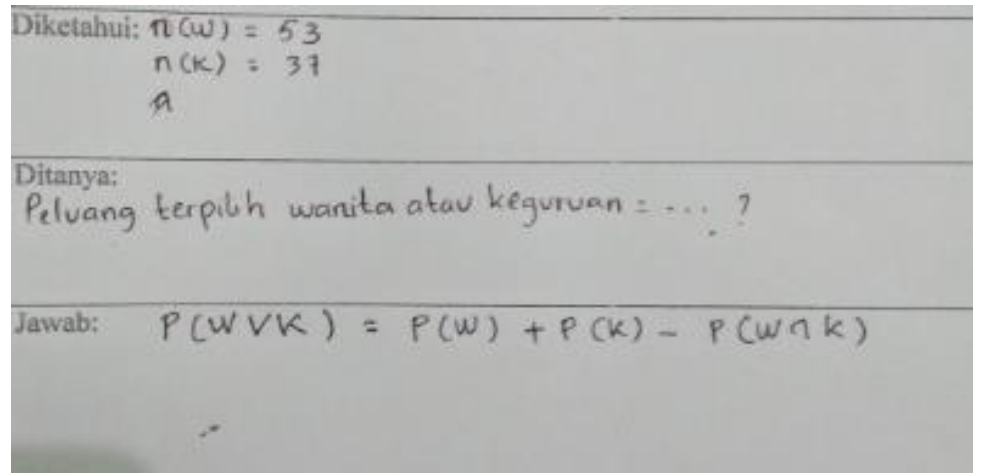

Gambar 4. Kesulitan siswa dalam keterampilan proses (sistematika penyelesaian)

Gambar 4 merupakan kesulitan siswa dalam mengurutkan sistematika penyelesaian. Siswa benar menentukan rumus dari peluang suatu kejadian sesuai masalah pada soal. Siswa tidak mampu menentukan nilai peluang terpilih wanita, peluang terpilih keguruan, dan peluang terpilih wanita irisan keguruan. Siswa fokus pada jumlah wanita dan jumlah keguruan, sehingga masuk pada tahap menggunakan rumus siswa tidak mampu mengerjakan karena siswa tidak mencari apa-apa yang dibutuhkan rumus. Berdasarkan jawaban siswa terlihat juga bahwa siswa tidak mampu mengaitkan jumlah sampel dengan peluang. Akibatnya, siswa tidak mampu menjawab soal dengan benar. Selanjutnya disajikan kesulitan siswa dalam menggunakan rumus yang merupakan bagian dari kesulitan dalam keterampilan proses (lihat Gambar 5).

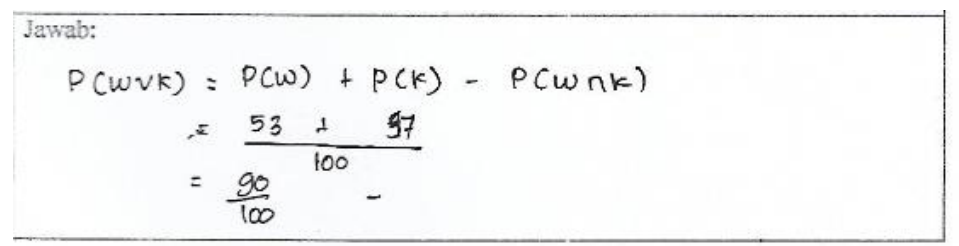

Gambar 5. Kesulitan siswa dalam keterampilan proses (menggunakan rumus)

Gambar 5 merupakan potret kesulitan siswa dalam menggunakan rumus yang digunakan. Pada kasus ini siswa sudah benar menentukan rumus namun keliru menggunakannya. Siswa tidak mampu menuliskan peluang irisan antara wanita dan keguruan. Akibatnya siswa terkendala tidak bisa melanjutkan ke tahap berikutnya. Kesulitan ini juga dikarenakan siswa tidak mampu menerima informasi yang disajikan tabel dengan benar. Berikut disajikan kesulitan siswa dalam menerapkan operasi dasar matematika (lihat Gambar 6).

Kesulitan dalam operasi dasar matematika juga dialami siswa dalam mengerjakan butir soal 4. Siswa sudah benar dalam menentukan apa yang diketahui, menentukan apa yang ditanya, menentukan dan menggunakan rumus. Namun, siswa keliru dalam menyelesaikan operasi dasar matematika, hal ini dapat disebabkan oleh siswa yang kurang teliti dan terburu-buru dalam mengerjakan. Temuan ini sejalan dengan penelitian-penelitian terdahulu. Blanco dan Garrote (2007, p. 227) dalam penelitiannya tentang kesulitan siswa dalam mengerjakan soal ketaksamaan siswa masih mengalami kesulitan proses aritmetika dan prosedur aljabar. Temuan Usman dan Hussaini (2017, p. 1) dalam penelitiannya di Nigeria menunjukkan bahwa kesalahan siswa dalam menyelesaikan masalah trigonometri adalah karena kelemahan mereka dalam operasi dasar matematika. 


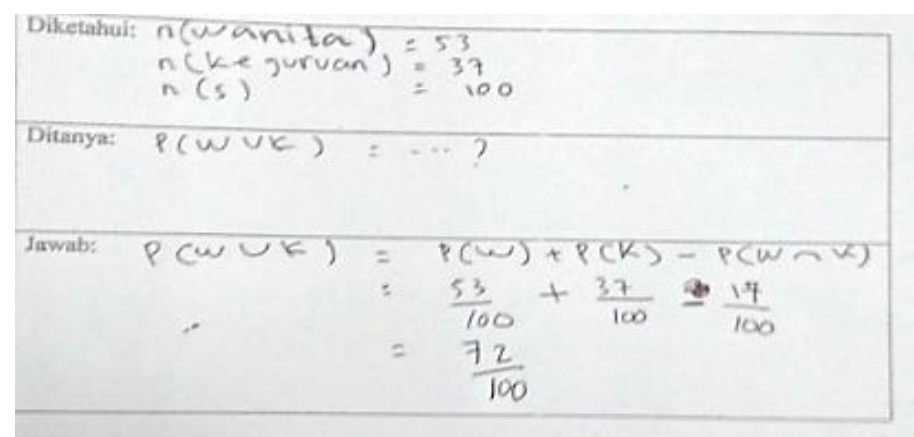

Gambar 6. Kesulitan siswa dalam keterampilan proses (operasi dasar)

Kesulitan menyimpulkan jawaban akhir (encoding) merupakan jenis kesulitan yang paling dominan dialami siswa. Prakitipong dan Nakamura (2006, p. 114) menyatakan bahwa siswa telah mampu mencapai tahap menarik kesimpulan apabila siswa dapat menuliskan jawaban dengan tepat dan lengkap. Dengan demikian, siswa dikatakan mengalami kesulitan dalam tahap ini jika siswa kurang lengkap dalam penulisan jawaban dari soal dengan tidak memberikan keterangan dari jawaban tersebut sesuai apa yang ditanyakan pada soal. Contoh kesalahan siswa dalam menarik kesimpulan disajikan pada Gambar 7.

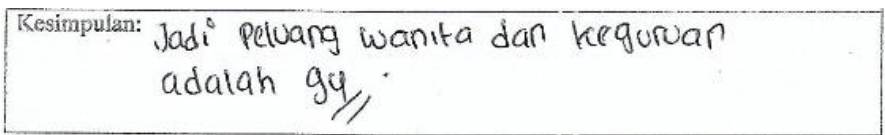

Gambar 7. Kesalahan siswa dalam menarik kesimpulan pada soal 1

Temuan tersebut sesuai dengan kajian Newman (White, 2005, p. 17) yang mengungkapkan bahwa dalam kesalahan menarik kesimpulan yang dilakukan siswa, siswa telah menemukan solusi atas permasalahan, tetapi salah dalam menentukan jawaban akhir, dan kajian Hansen et al. (2011, p. 11) yang mengungkapkan bahwa kesalahan menyimpulkan terjadi akibat ketidakmampuan untuk kembali memeriksa jawaban yang diperoleh. Selain itu, kesulitan ini juga sesuai dengan analisis Cooney et al. (1975, p. 226) bahwa siswa tidak mengecek kembali jawaban yang diperoleh dan tidak mampu menalar jawaban yang diperoleh apakah sudah tepat atau belum.

\section{SIMPULAN}

Berdasarkan hasil penelitian dan pembahasan, maka dapat disimpulkan bahwa jenis kesulitan yang dialami oleh siswa dalam menyelesaikan masalah non rutin materi peluang adalah yaitu kesulitan memahami masalah (comprehension errors), kesulitan transformasi (transformations errors), kesulitan keterampilan proses (processing skill errors), dan kesulitan dalam menarik kesimpulan (encoding errors). Temuan ini sekaligus mengungkapkan bahwa keterampilan siswa dalam menyelesaikan masalah matematika masih perlu ditingkatkan. Untuk itu, kami merekomendasikan kepada pendidik untuk dapat merancang pembelajaran matematika yang tidak hanya sekedar fokus pada transfer konsep, tetapi juga melatihkan siswa untuk mengembangkan kemampuan pemecahan masalah. Selain itu, disarankan kepada peneliti lain untuk menyelidiki dan mengungkap faktor eksternal dan internal yang menjadi penyebab kesulitan siswa dalam memecahkan masalah matematika.

\section{DAFTAR PUSTAKA}

Abdullah, A. H., Abidin, N. L. Z., \& Ali, M. (2015). Analysis of students errors in solving higher order thinking skills (HOTS) problems for the topic of fraction. Asian Social Science, 11(21), 133-142. https://doi.org/10.5539/ass.v11n21p133

Blanco, L. J., \& Garrote, M. (2017). Difficulties in learning inequalities in students of the first year of pre-university education in Spain. Eurasia Journal of Mathematics Science \& Technology Education, 3(3), 221-229. https://doi.org/10.12973/ejmste/75401

Cooney, T. J., Davis, E. V., \& Henderson, K. B. (1975). Dinamics of teaching secondary school mathematics. Houghton Mifflin. 
Dundar, S., \& Yaman, H. (2015). How do prospective teachers solve routine and non routine trigonometry problems? International Online Journal of Educational Sciences, 7(2), 41-57. https://doi.org/10.15345/IOJES.2015.02.010

Hansen, A., Drews, D., Dudgeon, J., Lawton, F., \& Surtees, L. (2011). Children's errors in mathematics (2nd ed.). Sage.

Kemendikbud. (2016). Peraturan Menteri Pendidikan dan Kebudayaan nomor 23 tahun 2016 tentang standar penilaian. https://bsnp-indonesia.org/wpcontent/uploads/2009/09/Permendikbud_Tahun2016_Nomor023.pdf

Krulik, S., \& Rudnick, J.A. (1995). Reasoning and problem solving. Allyn and Bacon.

NCTM. (2000). Principles and standards for school mathematics. National Council of Teachers of Mathematics.

Novferma, N. (2016). Analisis kesulitan dan self-efficacy siswa SMP dalam pemecahan masalah matematika berbentuk soal cerita. Jurnal Riset Pendidikan Matematika, 3(1), 76-87. https://doi.org/10.21831/jrpm.v3i1.10403

Phonapichat, P., Wongwanich, S., \& Sujiva, S. (2014). An analysing of elementary school students'difficulties in mathematical problem solving. Procedia Social and Beharioral Science, 116, 3169-3174. https://doi.org/10.1016/j.sbspro.2014.01.728

Polya, G. (1973). How to solve it: A new aspect of mathematical method (2nd ed.). Princeton University Press.

Prakitipong, N., \& Nakamura, S. (2006). Anaysis of mathematics performance of grade five students in Thailand using Newman procedure. Journal of International Cooperation in Education, 9(1), 111-122. https://doi.org/10.15027/34243

Reys, R., Lindquist, M., Lambdin, D. V., \& Smith, N. L. (2014). Helping children learn mathematics. John Wiley \& Sons.

Rumasoreng, M. I., \& Sugiman, S. (2014). Analisis kesulitan matematika Siswa SMA/MA dalam menyelesaikan soal setara UN di Kabupaten Maluku Tengah. Jurnal Riset Pendidikan Matematika, 1(1), 22-34. https://doi.org/10.21831/jrpm.v1i1.2661

Singh, P., Rahman, A. A., \& Hoon, S. T. (2010). The Newman procedure for analyzing primary four pupils errors on written mathematical task: A Malaysian perspective. Procedia Social and Behavioral Sciences, 8, 264-271. https://doi.org/10.1016/j.sbspro.2010.12.036

Usman, M. A., \& Hussaini, M. M. (2017). Analysis of students' error in learning of trigonometry amon senior secondary school students in Zaria Metropolis, Nigeria. IOSR Journal of Mathematics, 13(2), 1-4. https://doi.org/10.9790/5728-1302040104

Wagiran, W. (2015). Metodologi penelitian pendidikan: Teori dan implementasi. Budi Utama.

Wasda, M. R. (2015). Analisis kesulitan menyelesaikan soal model UN matematika dan self-efficacy siswa SMA di Kabupaten Ngada [Master's thesis, Universitas Negeri Yogyakarta].

White, A. L. (2005). Active mathematics in classrooms finding out why children make mistakes and then doing something to help them. Journal of The Primary Association for Mathematics, 15, 1519.

Wijaya, A., Heuvel-Panhuizen, M., Doorman, M., \& Robitzsch, A. (2014). Difficulties in solving context-based PISA mathematics tasks: An analysis of students' errors. The Mathematics Enthusias, 11(3), 555-584.

Yazgan, Y. (2015). Sixth graders and non-routine problems: Which strategies are decivise for success?. Educational Research and Reviews, 10(13), 1807-1816. https://doi.org/10.5897/ERR2015.2230

Zakaria, E. (2010). Analysis of student's error in learning of quadratic equations. International Education Studies, 3(3), 105-110. https://files.eric.ed.gov/fulltext/EJ1065893.pdf 